九州大学学術情報リポジトリ

Kyushu University Institutional Repository

\title{
Effect of Storage Temperature on Storage
} Efficacy, Germination and Physical Characters of Some Paddy Rice Cultivars during Different Storage Periods

\section{KATTA, Mohamed Youssef}

Agronomy Department, Faculty of Agriculture, Kafrelsheikh University

KAMARA, Mohamed Mohamed

Agronomy Department, Faculty of Agriculture, Kafrelsheikh University

ABD EL-ATY, Saad Mohamed

Agronomy Department, Faculty of Agriculture, Kafrelsheikh University

ELGAMAL, Hassan Waleed

Rice Research Department, Field Crops Research Institute, Agricultural Research Center 他

https://doi.org/10.5109/2232279

出版情報：九州大学大学院農学研究院紀要. 64 (1)，pp.61-69，2019-02-28. Faculty of Agriculture， Kyushu University

バージョン :

権利関係 : 


\title{
Effect of Storage Temperature on Storage Efficacy, Germination and Physical Characters of Some Paddy Rice Cultivars during Different Storage Periods
}

\author{
Youssef Mohamed KATTA ${ }^{1}$, Mohamed Mohamed KAMARA ${ }^{1}$, Mohamed Saad ABD EL-ATY ${ }^{1}$, \\ Waleed Hassan ELGAMAL ${ }^{2}$, Ramadan Mohamed SOLEIMAN ${ }^{1}$, \\ Kareem Mohamed MOUSA ${ }^{3,4}$ and Takatoshi UENO $^{4 *}$
}

Laboratory of Insect Natural Enemies, Division of Biological Control,

Department of Applied Genetics and Pest Management, Faculty of Agriculture, Kyushu University, Fukuoka 819-0395, Japan

(Received October 31, 2018 and accepted November 12, 2018)

\begin{abstract}
Postharvest loss is a serious problem in rice, and the loss during storage period can account for the majority of the postharvest loss. Traditional methods of storing paddy rice are vulnerable to insect and fungal infestations, leading to a considerable deterioration in rice quality. Here we focus on low-temperature storage to improve the storage efficacy of rice. Laboratory experiments were conducted to appraise the effects of storage temperature (traditional, cold and freeze storage) and period (6, 12, 18 and 24 months) on the storage efficacy such as pest and fungal infestations, germination success and physical quality of rice grains, using 11 paddy rice cultivars. Insect and fungal infestations significantly increased whereas germination success and rice quality were reduced, with increasing storage periods. Traditional storage of rice grains resulted in the highest levels of insect and fungal infestations caused by rice weevil, Alternaria sp., Nigrospora oryzae and Fusarium spp., while germination success and rice quality were relatively low. In contrast, cold storage satisfactorily lowered insect and fungal infestations while maximizing 1000-grain weight, germination success, hulling, milling and head rice. Although freeze storage of rice grains minimized the infestation levels, the other efficacy indices were inferior to those of cold storage. The impacts of the storage temperature and period were complicated depending on rice cultivars, which suggested that a further improvement of efficacy was possible by choosing the best cultivar suitable for storage. It is concluded that the cold storage $\left(5^{\circ} \mathrm{C}\right)$ can achieve the best storage efficacy to preserve the rice grains quality when storage period is up to 24 months.
\end{abstract}

Key words: postharvest loss, rice grain, Sitophilus oryza, fungal infestation, grain deterioration, traditional storage, seed fissures

\section{INTRODUCTION}

Effective grain storage techniques are now indispensable in many countries, and a strong demand to develop such techniques have been increasing to meet increasing subsistence requirements for food; about $70 \%$ extra food production will be desired by the year 2050 while a high level of grain loss can be more than 20\% (Hodges et al., 2011; Dowell and Dowell, 2017; Kumar and Kalita, 2017). During storage of grain, post-harvest loss may occur and the seed quality may decline to a level unacceptable for planting purposes, due to a number of abiotic and biotic reasons such as physical and physiological deterioration, pest insect infestation and fungal infection (Caldwell et al., 2005; Dowell and Dowell, 2017). Therefore, the grain storage technique has been one of the main subjects to reduce postharvest losses and to improve food production.

Rice (Oryza sativa L.) is a globally consumed by nearby half of the world's population and is an important

\footnotetext{
Agronomy Department, Faculty of Agriculture, Kafrelsheikh University, Egypt

2 Rice Research Department, Field Crops Research Institute, Agricultural Research Center, Egypt

3 Department of Economic Entomology, Faculty of Agriculture, Kafrelsheikh University, Egypt

${ }^{4}$ Institute of Biological Control, Faculty of Agriculture, Kyushu University, Fukuoka, Japan

* Corresponding author (E-mail: ueno@grt.kyushu-u.ac.jp)
}

food staple in the world (Muthayya et al., 2014), and reducing postharvest losses during storage of rice grain has been one of the central subjects in rice production (Kumar and Kalita, 2017). Storage period and condition have numerous impacts on the quality of rice grain or seed whereas, during the storage period, it is required to maintain the optimum physical and physiological features of the grain (Marques et al., 2014; Bhardwaj and Sharma, 2015; Sebastian and Selvaraju, 2017). Longer storage periods can also result in an increase of seed fissures and breakages (Sieben, 2000; Tsado et al., 2015). It was noticeable that the breakdown value decreased with increasing storage time, whereas the setback value seems to be increased (Kanlayakrit and Maweang, 2013).

Temperature also is a substantial biotic stress that affects both morphological and physiological features of rice during storage. The use of low-temperature storage system could efficaciously depress insect pest activities and mold growth (Banks and Fields, 1995; Kawamura et al., 2000) while storage at high temperature and/or humidity conditions could be deteriorative for rice growth and germination (Wang et al., 2018). Marques et al. (2014) and Jungtheerapanich et al. (2017) found that rice seeds stored in a natural environment or a high temperature condition showed lower physiological quality but those stored at a low temperature exhibited higher physiological and physical quality. Thus, temperature during storage, as well as storage period, should be an important factor affecting rice quality. Accordingly in 
the present study, we address how storage period and temperature could affect the quality of rice grain.

Marques et al. (2014) tested, with three rice cultivars, how storage periods could affect the seed quality and found that the periods had a significant impact on the quality depending on rice cultivars. Their study indicates that the magnitude of storage-period effects largely depends on the variety of rice. This may make sense because rice cultivars greatly vary in physiological and physical features (Singh et al., 2005). Upon assessing the impacts of storage periods (and other factors like temperature) on rice seed quality, it is therefore important to consider the interaction with rice cultivars. In Egypt, there are a number of rice cultivars but how the storage condition could affect the quality of Egyptian rice has not been examined well. Thus, in the present study, we focus also on how the impact of storage period and temperature on grain quality could interact with rice cultivars.

In addition, we evaluate the effect of storage periods on pest infestation and fungal infection. The storage periods can negatively affect rice grain quality through pest infestation and fungal infection because increasing periods should lead to significant proliferation of pest insects, rodents, fungi, and bacteria (Seadh et al., 2015; Sadaka et al., 2016). The rice weevil Sitophilus oryzae (L.) (Coleoptera: Curculionidae) is considered as one of the most important pests of rice grains in storage because the infestation by the weevil results in a considerable loss of the commercial value (e.g., Souza et al., 2012; Kamara et al., 2014; Nwaubani et al., 2014). An increase of the periods of storage causes an increased level of fissure of rice grain, which can lead to an increased level of $S$. oryzae infestation (Ribeiro et al., 2012). Thus, investigation of insect pest infestation and fungal infection during the storage of rice grains is important in the overall assessment of which storage condition is the best.

The present study was designed to investigate the effects of storage methods (temperature and period) on storage efficacy, germination and physical characters of paddy rice cultivars. We discuss rice storage techniques to improve paddy rice preservation and the best procedure for rice grain storage.

\section{MATERIALS AND METHODS}

\section{Experimental set-up}

Laboratory experiments were conducted at Sakha Agricultural Research Station, Agricultural Research Center (ARC), Egypt from November 2014 till November 2016, to examine the effects of storage conditions on quality and properties of rice grain. We set up different storage conditions in terms of the period and temperature; storage periods of $6,12,18$ and 24 months and temperatures of normal ( $=$ normal room temperature), cold (at $5^{\circ} \mathrm{C}$ ) and freeze (at $-5^{\circ} \mathrm{C}$ ). Thus, we prepared 12 groups of different storage conditions. For each group, experiments were carried out separately and each experimental group included 11 rice cultivars, i.e.,
Giza 177, Giza 178, Giza 179, Giza 182, Sakha 101, Sakha 102, Sakha 103, Sakha 104, Sakha 105, Sakha 106 and Egyptian Yasmen. In all, 132 experimental groups were finally set up, which were assigned in completely randomized design (CRD) with four replications for each group. For each replicate, a weight of $2 \mathrm{~kg}$ of grains with $14 \%$ moisture content in a gunny package was used.

\section{Storage efficacy}

To evaluate the storage efficacy under different storage conditions, grain weight, insect infestation and fungal infection were examined for each replicate. 1000grain weight (g) was measured after the storage period (6, 12, 18 and 24 months). Insect infestation was examined as follows: for each replicate (=each of a stored package), 100 grains were manually picked up from several depths for inspection. Grains with holes or infestation symptoms were collected for a close examination. This inspection procedure was repeated four times. The level of infestation was calculated as the percentage of damaged grains according to the following equation:

\section{Insect infestation percentage$$
=\frac{\text { Number of damaged grains }}{\text { Number of total grains inspected }} \times 100
$$

Detection of fungi was conducted as follows: Grains were examined for the presence of Alternaria sp., Nigrospora oryzae and Fusarium spp. by the Standard Blotter and Agar Plates Methods (ISTA, 1985). The percentage of infection by each fungal species was calculated using the following formula:

$$
\begin{aligned}
& \text { Occurance of species } \% \\
& \qquad=\frac{\text { Number ofdetected sambles }}{\text { Total number of samples }} \times 100
\end{aligned}
$$

\section{Germination test}

At the end of each storage period, a random sample of 100 seeds from each group (= package) was allowed to germinate under the environmental condition following the rules of International Seed Testing Association (ISTA, 1996), in which 25 seeds were placed on a filter paper in an antiseptic petri dish (14 cm in diameter). Germinated grains were counted at the fifth day, and, then, every 48 hours thereafter, till the end of germination test period (14 days). Germination percentages and indices were then calculated.

The final germination percentage (FG \%) was calculated as follows:

$$
F G \%=\frac{\text { Number of normal seedlings }}{\text { Number of total seeds }} \times 100
$$

Germination index (GI) was then estimated according to the following equation (Karim et al., 1992):

$$
G I \%=\frac{\text { Germination percentage in each }}{\text { treatment }} \times 100
$$




\section{Physical quality of rice grains}

Physical quality was evaluated by examining hulling, milling and head rice characteristics. After the designated storage period had ended (6, 12, 18 and 24 months), about $750 \mathrm{~g}$ of paddy rice was sampled from each package, and the following characters were examined: (1) hulling; (2) milling and (3) head rice (grading) percentages. Hulling percentage was examined by sampling $150 \mathrm{~g}$ of cleaned rough rice with $12-14 \%$ moisture content with an experimental huller machine. The percentage of hulling was determined according to Khush et al. (1979):

$$
\text { Hulling \% }=\frac{\text { Brown rice weight }}{\text { Rough rice weight }} \times 100
$$

Rice milling is the removal of brown rice as bran with the minimum breakage of the endosperm from dehulled grains, and the percentage of milling (=degree of white rice) is a good measure for rice physical quality. Samples were milled using McGILL Miller No.2 for $60 \mathrm{~s}$ and were then weighted. The percentage of total milled rice was calculated according to Ghosh et al. (1971) that is;

$$
\text { Milling } \%=\frac{\text { Milled rice weight }}{\text { Rough rice weight }} \times 100
$$

Finally, using a rice sizing device, the whole grains were detached from the total milled rice to measure head rice percentage, which is an important criteria for milled rice quality. The isolation of these particles is termed as "grading". The amount of head rice yield is then obtained and calculated (IRRI, 1996) as follows:

$$
\text { Head rice } \%=\frac{\text { Head rice weight }}{\text { Rough rice weight }} \times 100
$$

\begin{tabular}{|c|c|c|c|c|c|}
\hline Treatments & $\begin{array}{l}\text { 1000-grain } \\
\text { weight }(g)\end{array}$ & $\begin{array}{c}\text { Insect } \\
\text { infestation (\%) }\end{array}$ & $\begin{array}{c}\text { Alternara sp } \\
(\%)\end{array}$ & $\begin{array}{l}\text { Nigrospora } \\
\text { oryzae (\%) }\end{array}$ & $\begin{array}{c}\text { Fusarium spp } \\
\text { (\%) }\end{array}$ \\
\hline \multicolumn{6}{|l|}{ A-Storage periods: } \\
\hline 6 months & 24.78 & 4.74 & 7.79 & 3.42 & 5.36 \\
\hline 12 months & 24.66 & 7.21 & 8.95 & 4.19 & 6.67 \\
\hline 18 months & 24.90 & 9.69 & 9.66 & 4.87 & 8.43 \\
\hline 24 months & 24.43 & 12.76 & 11.02 & 5.49 & 8.65 \\
\hline F test & $*$ & $*$ & $*$ & * & * \\
\hline \multicolumn{6}{|l|}{ B-Storage methods: } \\
\hline Normal storage & 24.33 & 25.80 & 13.94 & 6.60 & 12.44 \\
\hline Cold storage & 24.97 & 0.00 & 7.89 & 3.86 & 5.28 \\
\hline Freeze storage & 24.78 & 0.00 & 6.24 & 3.02 & 4.11 \\
\hline F test & $*$ & * & * & * & $*$ \\
\hline \multicolumn{6}{|l|}{ C-Rice cultivars: } \\
\hline Giza 177 & 23.35 & 9.84 & 15.12 & 6.80 & 12.08 \\
\hline Giza 178 & 20.84 & 7.60 & 10.82 & 3.75 & 6.58 \\
\hline Giza 179 & 23.78 & 12.13 & 8.30 & 5.47 & 5.88 \\
\hline Giza 182 & 27.64 & 10.03 & 8.86 & 4.04 & 4.30 \\
\hline Sakha 101 & 26.02 & 6.99 & 10.31 & 3.67 & 8.55 \\
\hline Sakha 102 & 24.98 & 5.86 & 10.66 & 3.99 & 6.10 \\
\hline Sakha 103 & 24.60 & 6.83 & 8.53 & 3.78 & 6.46 \\
\hline Sakha 104 & 25.05 & 6.68 & 11.03 & 4.63 & 9.78 \\
\hline Sakha 105 & 26.06 & 6.66 & 8.33 & 4.97 & 6.03 \\
\hline Sakha 106 & 26.25 & 6.58 & 5.75 & 3.71 & 6.29 \\
\hline Egyptian Yasmen & 23.08 & 15.38 & 5.21 & 4.63 & 7.96 \\
\hline F test & $*$ & $*$ & $*$ & $*$ & $*$ \\
\hline \multicolumn{6}{|l|}{ D-Interactions: } \\
\hline $\mathrm{A} \times \mathrm{B}$ & $*$ & NS & NS & $*$ & NS \\
\hline $\mathrm{A} \times \mathrm{C}$ & $*$ & NS & * & $*$ & $*$ \\
\hline $\mathrm{B} \times \mathrm{C}$ & * & NS & * & $*$ & $*$ \\
\hline $\mathrm{A} \times \mathrm{B} \times \mathrm{C}$ & $*$ & NS & NS & $*$ & NS \\
\hline
\end{tabular}

Table 1. Means of 1000-grain weight, insect and fungal infestations as affected by storage periods and methods and rice cultivars

* significantly different. 




Fig. 1. 1000-grain weight as affected by the interaction between storage periods, storage methods and rice cultivars.

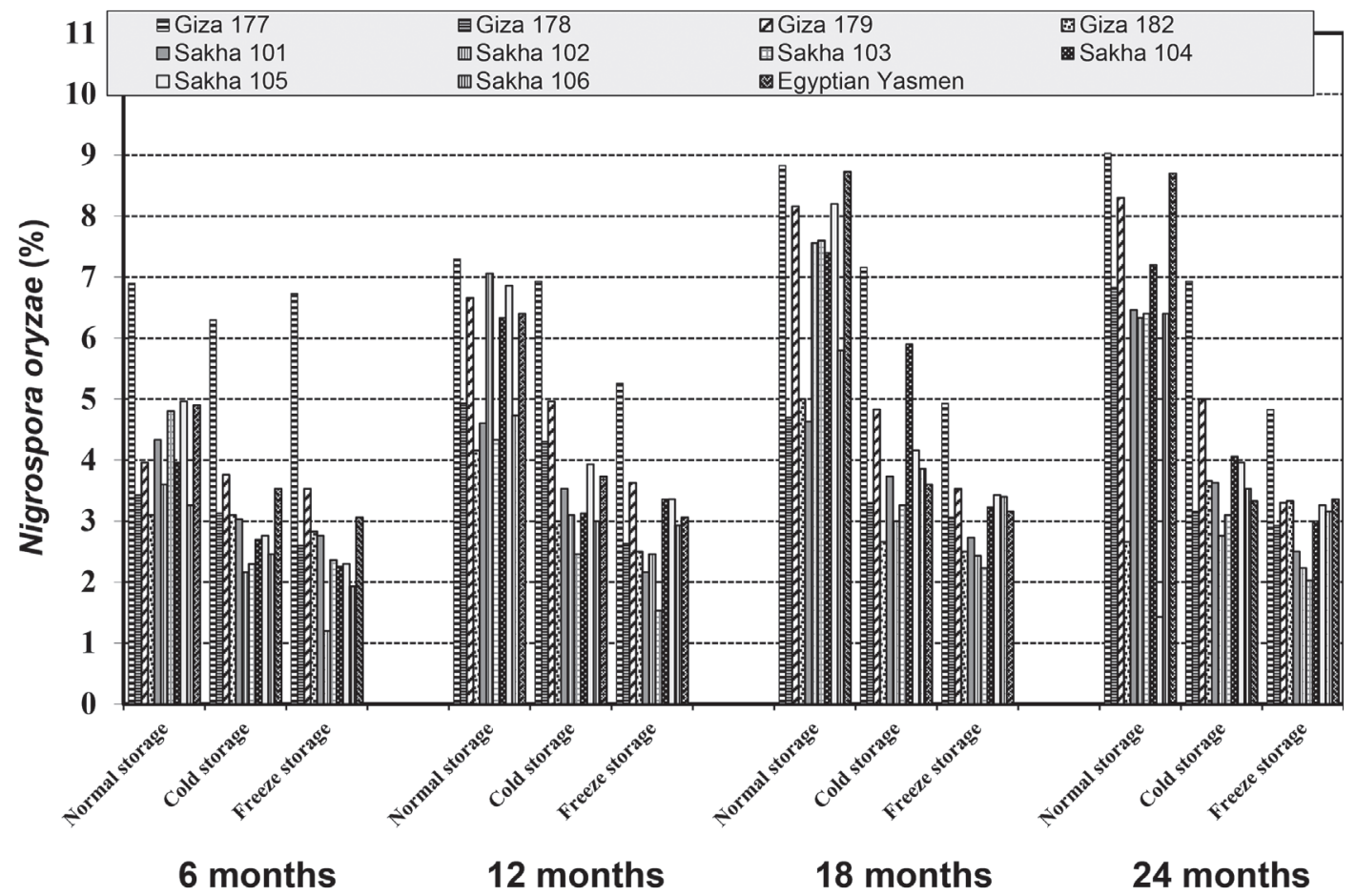

Fig. 2. Infestation by Nigrospora oryzae (\%) as affected by the interaction between storage periods, storage methods rice cultivars. 


\section{Statistical analyses}

All data were statistically analyzed with analysis of variance (ANOVA) for the completely randomized block (CRD), and, then, a combined analysis was done between storage methods and storage periods as published by Gomez and Gomez (1984) using "MSTAT-C" computer software package. Means of treatments were compared using Duncan's multiple range tests at 5\% level of probability as described by Duncan (1955). The arcsin square-root transformation was made before analyzing the percentage data; non-transformed data were presented in the Results.

\section{RESULTS}

\section{Effect of storage periods}

Storage periods of rice grains $(6,12,18$ and 24 months) had significant effects on storage efficacy characters, i.e., 1000-grain weight, insect infestation and fungal infection, germination success and physical quality of rice, as shown in Tables 1 and 2. Overall comparison of the mean values of 1000-grain weight suggested a relatively weak effect of storage periods and temperatures but this was largely due to a great variation of the weight among the rice cultivars examined in the present study (Table 1 and Fig. 1). Nevertheless, the 100-gain weight was heaviest in cold storage method (Table 1).

The rice weevil Stophilus oryzae was the most dominant insect pest among all inspected specimens. The present analysis showed a clear relationship between storage period and infestation by $S$. oryzae; as the period increased, the percentages of infested rice increased (Table 1). Also, in our study, we detected three groups of fungi, i.e., Alternaria sp., Nigrospora oryzae and Fusarium spp. Fungal infestation significantly increased with increasing storage periods from 6

Table 2. Means of final germination percentage, germination index, hulling, milling and head rice percentages as affected by storage periods and methods and rice cultivars

\begin{tabular}{|c|c|c|c|c|c|}
\hline Treatments & $\begin{array}{c}\text { Final } \\
\text { germination }(\%)\end{array}$ & $\begin{array}{c}\text { Germination } \\
\text { index }\end{array}$ & Hulling (\%) & Milling (\%) & Head rice (\%) \\
\hline \multicolumn{6}{|l|}{ A-Storage periods: } \\
\hline 6 months & 87.94 & 0.935 & 77.54 & 66.47 & 56.78 \\
\hline 12 months & 85.90 & 0.932 & 75.58 & 65.23 & 57.48 \\
\hline 18 months & 82.64 & 0.927 & 74.66 & 64.26 & 55.73 \\
\hline 24 months & 81.41 & 0.920 & 73.61 & 63.60 & 55.16 \\
\hline F. test & $*$ & $*$ & $*$ & $*$ & $*$ \\
\hline \multicolumn{6}{|l|}{ B-Storage methods: } \\
\hline Normal storage & 81.99 & 0.894 & 72.96 & 63.62 & 53.61 \\
\hline Cold storage & 87.84 & 0.950 & 78.14 & 67.42 & 61.84 \\
\hline Freeze storage & 83.59 & 0.942 & 74.94 & 63.63 & 53.41 \\
\hline F. test & $*$ & $*$ & $*$ & $*$ & $*$ \\
\hline \multicolumn{6}{|l|}{ C-Rice cultivars: } \\
\hline Giza 177 & 87.66 & 0.948 & 75.97 & 66.69 & 58.56 \\
\hline Giza 178 & 81.44 & 0.960 & 75.21 & 64.21 & 54.20 \\
\hline Giza 179 & 81.33 & 0.952 & 75.03 & 65.03 & 53.77 \\
\hline Giza 182 & 84.04 & 0.904 & 73.89 & 61.43 & 51.38 \\
\hline Sakha 101 & 81.80 & 0.900 & 76.57 & 65.61 & 60.51 \\
\hline Sakha 102 & 84.97 & 0.916 & 76.27 & 65.54 & 56.84 \\
\hline Sakha 103 & 86.58 & 0.924 & 74.70 & 64.93 & 53.84 \\
\hline Sakha 104 & 86.36 & 0.922 & 75.38 & 65.50 & 61.13 \\
\hline Sakha 105 & 84.63 & 0.916 & 75.67 & 64.55 & 55.41 \\
\hline Sakha 106 & 86.27 & 0.914 & 75.86 & 66.11 & 59.33 \\
\hline Egyptian Yasmen & 84.13 & 0.959 & 74.25 & 64.20 & 54.15 \\
\hline F. test & $*$ & $*$ & $*$ & $*$ & $*$ \\
\hline \multicolumn{6}{|l|}{ D-Interactions: } \\
\hline$A \times B$ & $*$ & $*$ & $*$ & $*$ & $*$ \\
\hline $\mathrm{A} \times \mathrm{C}$ & $*$ & NS & $*$ & $*$ & $*$ \\
\hline $\mathrm{B} \times \mathrm{C}$ & $*$ & $*$ & $*$ & $*$ & $*$ \\
\hline $\mathrm{A} \times \mathrm{B} \times \mathrm{C}$ & $*$ & NS & $*$ & NS & $*$ \\
\hline
\end{tabular}

* significantly different. 
to 24 months, regardless of the fungi groups (Table 1 and Fig. 2). Thus, the highest insect infestation and fungal infection were observed in paddy rice stored for 24 months.

The percentages of final germination decreased as the storage periods increased (Table 2 and Fig. 3). Further, physical characters (hulling, milling and head rice percentages) were significantly decreased as a result of increasing in storage periods of paddy rice grains from 6 to 24 months (Fig. 4 and 5). Thus, the highest final germination percentage, germination index, hulling and milling percentages were obtained from rice grains stored for 6 months, i.e., the shortest period of storage.

\section{Effect of storage temperature}

The results together with statistical presentation were summarized in Tables 1 and 2. Evidently, storage methods (traditional storage at $25^{\circ} \mathrm{C}$, cold storage at $5^{\circ} \mathrm{C}$ and freeze storage at $-5^{\circ} \mathrm{C}$ ) had significant effects on all measurements regarding storage efficacy characters examined in the present studies, i.e., 1000-grain weight, insect and fungal infestations, germination success, and technological characters of rice grains. The traditional storage under normal room temperature of rice grains resulted in significantly higher levels of infestation by rice weevil and greater probabilities of detection of Alternaria sp., Nigrospora oryzae and Fusarium spp. than the cooling or freeze storage methods.

Over storage periods, the highest values of 1000 grain weight, final germination percentage, hulling, mill- ing and head rice percentages were resulted from cold storage of rice grains (at $5^{\circ} \mathrm{C}$ ), followed by freeze storage of rice grains (at $-5^{\circ} \mathrm{C}$ ); normal storage was worst in terms of the measurements mentioned above. Whereas the highest values of germination index produced from freeze storage of rice grains (at $-5^{\circ} \mathrm{C}$ ) followed by cold storage (at $5^{\circ} \mathrm{C}$ ) and then normal storage of rice grains.

\section{Cultivar dependence}

The rice cultivars examined, i.e., Giza 177, Giza 178, Giza 179, Giza 182, Sakha 101, Sakha 102, Sakha 103, Sakha 104, Sakha 105, Sakha 106 and Egyptian Yasmen cultivars, significantly differed in storage efficacy characters, as shown in Tables 1 and 2. For example, Giza 182 cultivar registered the highest values of 1000-grain weight over storage periods. Giza 177 cultivar showed the highest insect and fungal infestations whereas the final germination and milling percentages over storage periods were greatest. Giza 178 was a cultivar showing the highest germination index. Also, significant interactions were detected between rice cultivars and the other variables measured in the present study (Tables 1 and $2)$. The interactions were rather complicated, and, to illustrate complicate interactions, the percentages of final germination, hulling and head rice in relation to rice cultivars are figured in Figs. 3, 4 and 5.

\section{DISCUSSION}

Temperature, storage location, grain handling and varieties are considered to be important factors influenc-

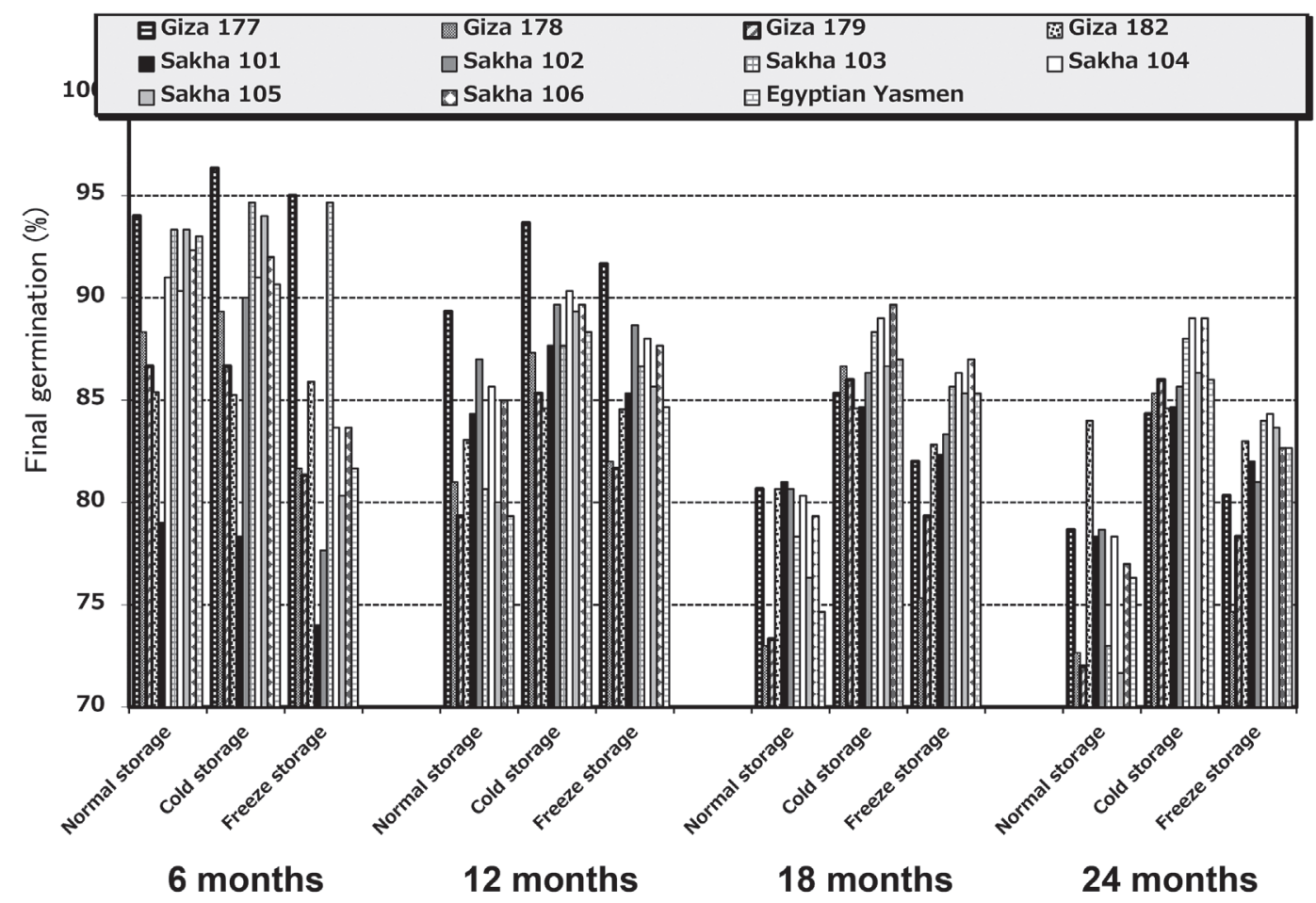

Fig. 3. Final germination (\%) as affected by the interaction between storage periods, storage methods and rice cultivars. 


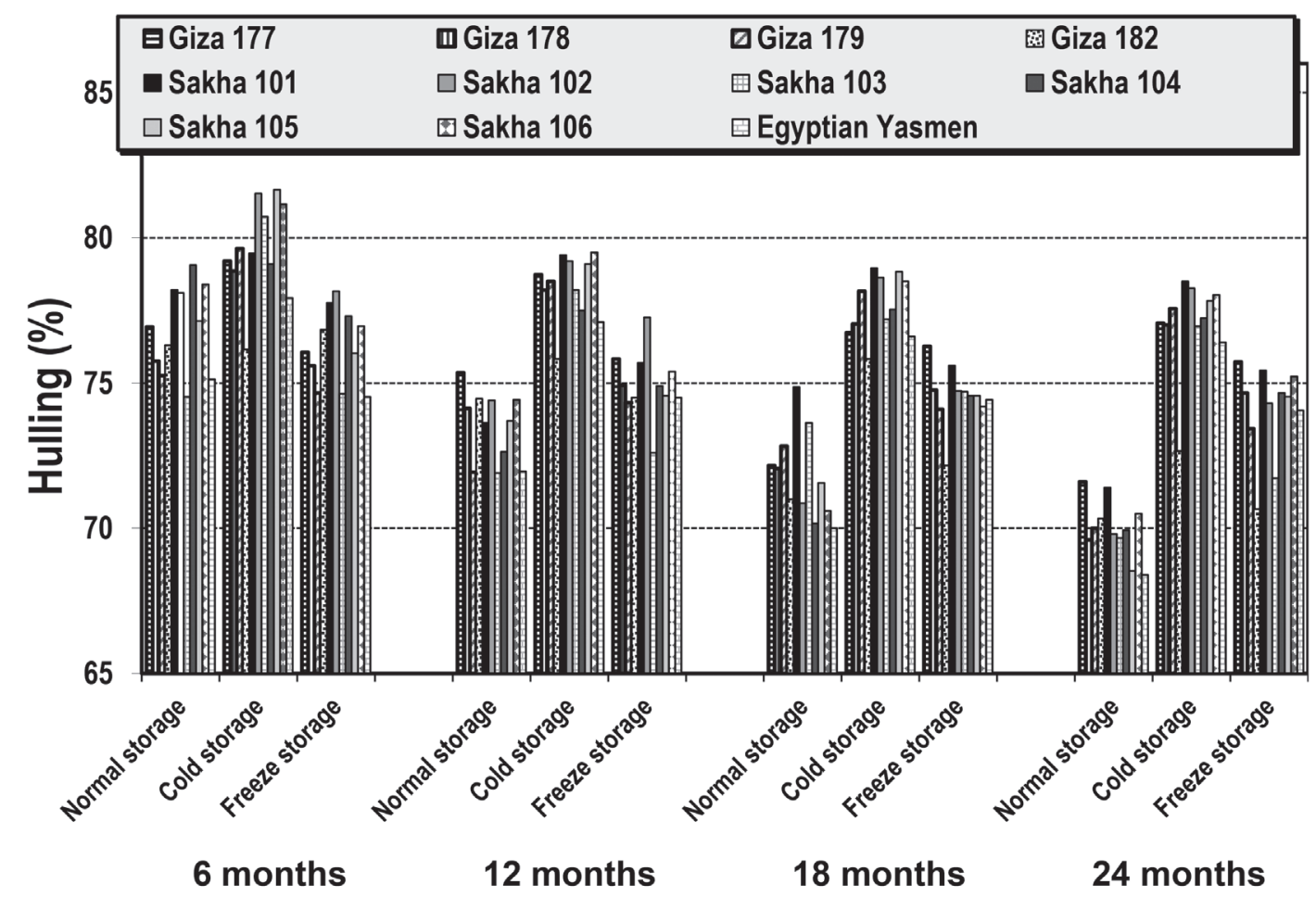

Fig. 4. Hulling (\%) as affected by the interaction between storage periods, storage methods and rice cultivars.

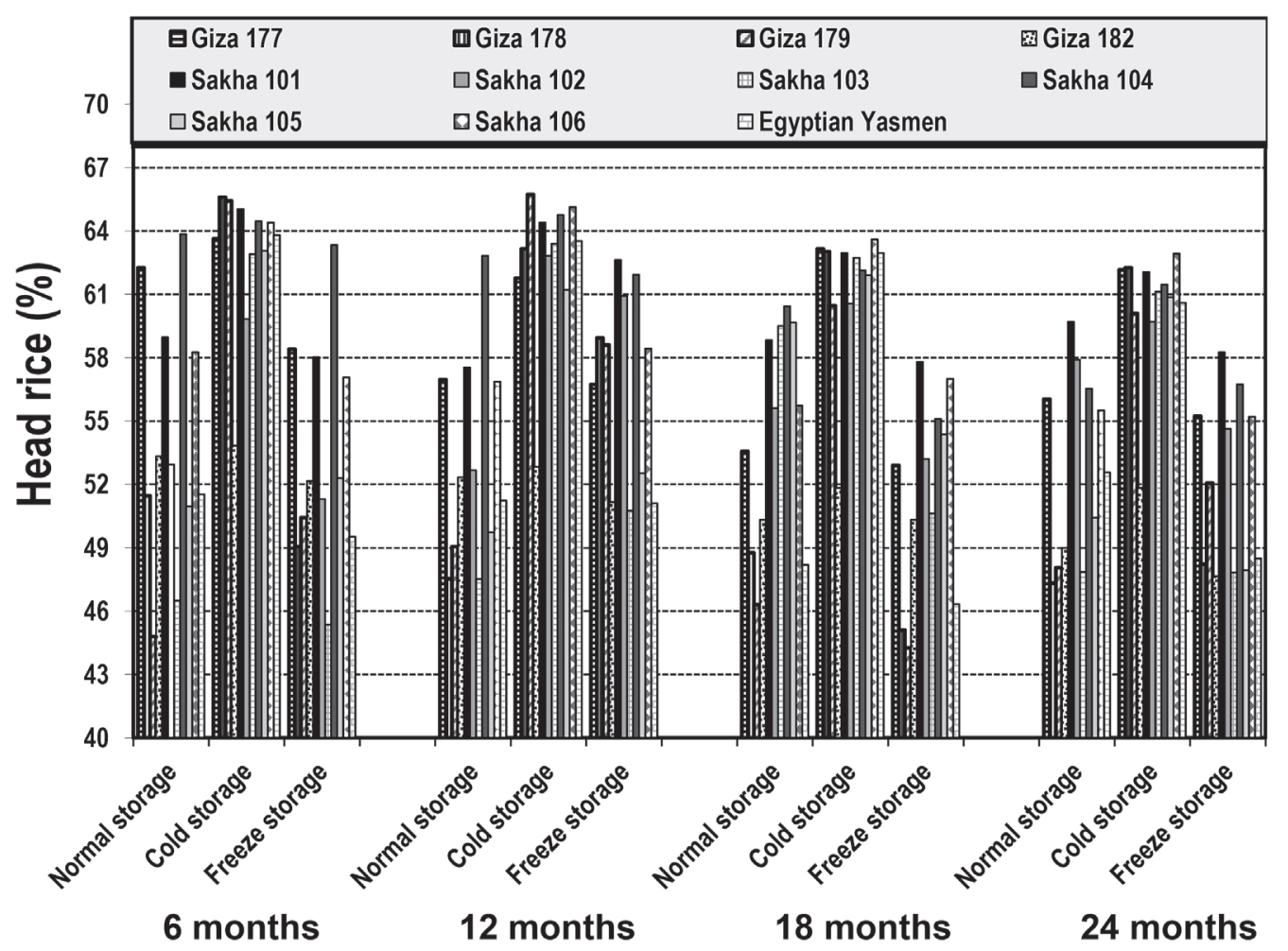

Fig. 5. Head rice (\%) as affected by the interaction between storage periods, storage methods and rice cultivars. 
ing the stored grains quality including physical and physiological features of the grains (Đukanovićand Sabovljević, 2001; Marques et al., 2014; Sebastian and Selvaraju, 2017). Unwelcome organisms such as fungi, bacteria, insects, and rodents can often be involved in reduced grain quality and loss during storage (Seadh et al., 2015; Sadaka et al., 2016). Also, grain deterioration during storage might be due to the spoilage in membrane, enzyme, proteins and nucleic acid, in addition to accumulation such degenerative changes with time, which can result in complete disorganization in cell organelles (Sadaka et al., 2016). During storage, a numerous changes in physicochemical and physiological features occur including changes in color, flavor, and composition (Suzuki et al., 1999).

In the present study, we have shown, with Egyptian rice cultivars, that the storage period and temperature greatly affect the severity of insect and fungal infestation, germination success and physical quality of rice grains. Our findings are mostly consistent with previous studies focusing the effects of storage period and temperature on rice grains (e.g., Tsado et al., 2015; El-Dalil, 2017; Jungtheerapanich et al., 2017; Sebastian and Selvaraju, 2017).

Temperature is an important abiotic stress that can affect rice quality during storage. It is also known that the low temperature storage can minimize feeding, reproduction, development and survival of insect pests and fungi (Fields, 1992) because their development, survival and reproduction are largely dependent on temperature (e.g., Virachack et al., 2018). For example, the development, reproduction and infestation of insect pests attacking stored products slow down below $20^{\circ} \mathrm{C}$, and cooling to temperature below $13^{\circ} \mathrm{C}$ can prevent the reproduction and development (Field, 1992; Banks and Fields, 1995). Therefore, low temperature storage can be considered as an alternative method to chemical control of stored grain insect pests (Fields, 1992), though organic based pesticides may be a good option (Mousa et al., 2013; Tran et al., 2016, 2017). In the present study, we have demonstrated that the infestation by the rice weevil is $25.8 \%$ under a room temperature condition but it becomes $0 \%$ when the storage temperature is $5^{\circ} \mathrm{C}$ or $-5^{\circ} \mathrm{C}$ (Table 1). Thus, low temperature storage is an effective method to prevent grain loss caused by the rice weevil.

Likewise, cold storage of rice grains is effective to maintain the physical quality of rice grain, regardless of rice cultivars (Table 2). We have demonstrated that 1000-grain weight, hulling, milling and head rice percentages are improved by cold storage probably due to reductions of physiological activities and cracked grains, which consequently maintains better rice quality. Several previous studies also reported similar findings. For example, low storage temperature efficiently leads to a decrease in breakdown grains and an increase in head rice compared with higher storage temperature (Jungtheerapanich et al., 2017). Also, stored rice at room or high temperature conditions is reported to be of low quality (Marques et al., 2014; Mutinda et al., 2017;
Naik and Chetti, 2017).

We also have shown that the effects of storage periods and temperatures largely depend on rice cultivars tested in our study (Figs. 1-5). The differences among Egyptian rice cultivars in storage efficacy, germination and technological characters maybe related to genetic factors. Resistance against pest insects can depend upon physiological and physical traits among different cultivars, such as chemical composition, moisture contents, etc., which may profoundly affect, the suitability for oviposition and development of the pests (Khokhar and Gupta, 1974). Also, grain characteristics such as phenolic, protein and amylase contents differ among cultivars, which may associate with different levels of vulnerability to stored product insect pests (Chanbang et al., 2008) and with the presence of variable pathogenic and non-pathogenic fungi in rice seeds (Uma and Wesely, 2013).

Postharvest loss is a serious problem in many countries. The magnitude of the loss varies depending on crops, climatic conditions and storage practices but the loss during storage period can account for the majority of postharvest losses. This is particularly true for the traditional storage practice in which pest infestation and fungal infection are usually severe. Also, uncontrolled environments in the traditional storage cause reduced physical and physiological quality of grains.

The primary purpose of this study was to evaluate the impact of storage temperature and period on insect and fungal infestation, physical characters, and germination success of paddy rice. Basing on the present results, we recommended that cold storage at $5^{\circ} \mathrm{C}$ is the most adequate method of rice grains, regardless of rice cultivars, when prolonging storage periods until 24 months.

\section{AUTHOR CONTRIBUTIONS}

M. M. Kamara, Y. M. Katta, M. S. Abd El-Aty and W. H. Elgamal contributed in the experiment design, data analysis and also helped during the experiments performance. R. M. Soleiman performed the experiments, analyzed the data and prepared the first draft of the manuscript. K. M. Mousa contributed in manuscript preparation and discussed the results. T. Ueno participated in manuscript preparation and polished up the manuscript.

\section{CONFLICT OF INTEREST}

The authors declare no conflicts of interest.

\section{REFERENCES}

Banks, H. J. and P. G. Fields 1995 Physical methods for insect control in stored grain ecosystem. In "Stored-grain Ecosystems", eds by D.S. Jayas, N. D. G. White and W. E. Muir, Marcel Dekker Inc., New York, pp. 353-410

Bhardwaj, S. and R. Sharma 2015 Recent advances in on-farm paddy storage. Inter. J. Farm Sci., 5: 265-272

Caldwell, C. R., S. J. Britz and R. M. Mirecki 2005 Effect of temperature, elevated carbon dioxide, and drought during seed develop- 
ment on the isoflavone content of dwarf soybean Glycine max (L.) Merrill grown in controlled environments. J. Agric. Food Chem., 53: 1125-1129

Chanbang, Y., F. H. Arther, G. E. Wilde and J. E. Tron 2008 Hull characteristics as related to susceptibility of different varieties of rough rice to Rhyzopertha dominica (F.) (Coleoptera: Bostrichidae). J. Stored Prod. Res., 44: 205-212

Dowell, F. E. and C. N. Dowell 2017 Reducing grain storage losses in developing countries. Q. Assur. Safe. Crops Foods, 9: 93-100

Đukanović, L. and R. Sabovljević 2001 Change of maize seed traits under different modes of storing. Proceedings of 12th Conference of Agronomist, Veterinarians and Technologiest. Institut PKB Agroekonomik, Belgrade, Serbia, 7: 41-49

El-Dalil, M. A. E. 2017 Effect of parboiling and storage periods on grain quality characters of G179 rice cultivar. Alexandria Sci. Exch. J., 38: 537-542

Fields, P. G. 1992 The control of stored-product insects and mites with extreme temperatures. J. Stored Prod. Res., 28: 89-118

Ghosh, A. K., B. B. Nanda, S. Govindaswamy and B. B. Nayak 1971 Influence of nitrogen on the physicochemical characteristics of rice grain. Oryza, 8: 87-98

Gomez, K. A. and A. A. Gomez 1984 Statistical Procedures for Agricultural Research, 2nd ed. John Wiley and Sons, New York

Hodges, R. J., J. C. Buzby and B. Bennett 2011 Postharvest losses and waste in developed and less developed countries: Opportunities to improve resource use. J. Agric. Sci., 149: $37-45$

International Rice Research Institute (IRRI) 1996 Standard Evaluation System for Rice. IRRI, Manila, Philippines

International Seed Testing Association "ISTA" 1985 International rule for seed health testing. Seed Sci. Technol., 13: 307-355

ISTA 1996 International Rules for Seed Testing. The International Seed Testing Association, Zurich

Jood, S., A. C. Kapoor and S. Ram 1996 Evaluation of some plant products against Trigoderma granarium Everts in Sorghum and their effects on nutritional composition and oranoleptic characteristics. J. Stored Prod. Res., 32: 345-352

Jungtheerapanich, S., K. Tananuwong and J. Anuntagool 2017 Aging kinetics of low amylose rice during storage at ambient and chilled temperatures. Int. J. Food Prop., 20: 1904-1912

Kamara, J. S., S. M. Kanteh, S. M. Bockari-Gevao and S. Jalloh 2014 Infestation, population density and sterilization effects on rice weevils (Sitophilus oryzae L.) in stored milled rice grains in Sierra Leone. Inter. J. Agric. Forest., 4: 19-23

Kanlayakrit, W. and M. Maweang 2013 Postharvest of paddy and milled rice affected physicochemical properties using different storage conditions. Int. Food Res. J., 20: 1359-1366

Karim, M. A., N. Utsunomiya and S. Shigenaga 1992 Effect of sodium chloride on germination and growth of hexaploid triticale at early seedling stage. Jap. J. Crop Sci., 61: 279-284

Kawamura, S., K. Takekura, T. Ogawa and K. Hoh 2000 Long-term storage of rough rice at temperatures below ice point. ASAE Paper No. 00-6041. S1., Joseph, Mich., ASAE

Khokhar, D. S. and D. S. Gupta 1974 Relative resistance of some varieties of wheat to Sitophilus oryzae (L.) and Rhyzopertha dominica (F.) at different temperatures. Bull. Grain Technol., 12: $117-123$

Khush, G. S., C. M. Paule and N. M. Dela Cruz 1979 Rice grain quality evaluation and improvement at IRRI. The Workshop on "Chemical Aspects of Rice Grain Quality", IRRI, Los Banos, Philippines

Kumar, D. and P. Kalita 2017 Reducing postharvest losses during storage of grain crops to strengthen food security in developing countries. Foods, 6: 8

Marques, E. R., E. F. Araújo, R. F. Araújo, S. M. Filho and P. C. Soares 2014 Seed quality of rice cultivars stored in different environments. J. Seed Sci., 36: 32-39

Mousa K. M., I. A. Khodeir, T. N. El-Dakhakhni and A. E. Youssef
2013 Effect of Garlic and Eucalyptus oils in comparison to organophosphate insecticides against some piercing-sucking Faba bean insect pests and natural enemies populations. Egypt. Acad. J. Biolog. Sci., 5: 21-27

Muthayya, S., J. D. Sugimoto, S. Montgomery and G. F. Maberly 2014 An overview of global rice production, supply, trade, and consumption. Ann. N. Y. Acad. Sci., 1324: 7-14

Mutinda, Y. A., J. W. Muthomi, J. M. Kimani, G. N. Cheminigwwa and F. M. Olubayo 2017 Viability and dormancy of rice seeds after storage and pre-treatment with dry heat and chemical agents. $J$. Agric. Sci., 9: 175-185

Naik, D. S. and M. B. Chetti 2017 Effect of storage conditions and packaging on sensory evaluation of rice. Intern. J. Curr. Microbiol. Appl. Sci., 6: 1219-1230

Nwaubani S. I., G. P. Opit, G. O. Otitodun and M. A. Adesida 2014 Efficacy of two Nigeria derived diatomaceous earths against Sitophilus oryzae (Coleoptera: Curculionidae) and Rhyzopertha dominica (Coleoptera: Bostrichidae) on wheat. $J$. Stored Prod. Res., 59: 9-16

Ribeiro, C. S. N., G. V. Martins, J. F. R. Guimarães, E. F. Silva 2012 Resistência de genótipos de arroz a pragas de grãos armazenados. Caatinga, 25: 183-187

Sadaka, S., G. Atungulu and G. Olatunde 2016 Safe Grain Storage Period. Agric. and Nat. Res., Division of Agric. Res. \& Ext., Univ. of Arkansas System, FSA1058

Seadh, S. E., A. N. Attia, M. A. Badawi and I. H. S. Shwan 2015 Physical and technological characters of milled rice as affected by storage periods, treating with phosphine and oil neem and packages types. Global J. Biol. Agric. Health Sci., 4: 61-70

Sebastian, A. and P. Selvaraju 2017 Influence of temperature of production environment on seed quality and storability of rice genotypes. Inter. J. Curr. Microbiol. Appl. Sci., 6: 4273-4284

Sieben T. 2000 Rice fissuring response to high drying and tempering temperature. Food Engineering, 59: 61-69

Silva, A. S., L. P. Schmid, F. Mielezrski and B. E. Pavan 2018 Physiological quality of rice seeds stored in different environments and packages. J. Exp. Agric. Inter., 23: 1-9

Singh, N., L. Kaur, S. S. Singh and K. S. Sekhon 2005 Physiochemical, cooking and textural properties of milled rice from different Indian rice cultivars. Food Chem., 89: 253-259

Souza, A. R., T. M. Silva and J. F. L. Santos 2012 Seleção e desenvolvimento de Sitophilus oryzae (Linné, 1763) em três substratos. Magistra, 24: 160-163

Suzuki, Y., K. Ise, C. Li, I. Honda, Y. Iwai and U. Matsukura 1999 Volatile components in stored rice (Oryza sativa L.) of varieties with and without lipoxygenase-3 in seeds. J. Agric. Food Chem., 47: 1119-1124

Tran, D. H., K. P. Le, H. D. T. Tran and T. Ueno 2016 Control efficacy of pongam (Pongamia pinnata L.) leaf extract against the turnip aphid Lipaphis pseudobrassicae (Davis) (Hemiptera: Aphididae). J. Fac. Agric., Kyushu Univ., 60: 141-145

Tran, D. H., M. Takagi and T. Ueno 2017 Efficacy of the extract from pongam leaves (Pongamia pinnata L.) against Spodoptera exigua (Hübner) and Spodoptera litura Fabricius (Lepidoptera: Noctuidae). J. Fac. Agric., Kyushu Univ., 62: 439-443

Tsado, E. K., A. S. Gana, S. T. Yusuf, E. Daniya and A. Musa 2015 Effect of storage period of paddy rice on grain fissures and breakages of milled rice. J. Environ. Sci. Toxic. Food Tech., 9: 8-17

Uma, V. and E. G. Wesely 2013 Seed borne fungi of rice from South Tamil Nadu. J. Acad. Indus. Res., 1: 612-614

Virachack, H., H. G. Trinh, T. T. G. Ho and T. Ueno 2018 Temperature effects on the development of Vietnamese cotton bollworm Helicoverpa armigera (Hübner). J. Fac. Agric., Kyushu Univ., 63: 303-309

Wang W., A. He, S. Peng, J. Huang, K. Cui and L. Nie 2018 The effect of storage condition and duration on the deterioration of primed rice seeds. Front. Plant Sci., 9: Article 172 